\title{
APPLICABILITY AND SENSITIVITY OF PCR-SSCP METHOD FOR MILK SPECIES IDENTIFICATION IN CHEESE
}

\author{
A. Csikos $^{\mathrm{a}}$, A. Hodzic ${ }^{\mathrm{b}}$, E. Pasic-Juhas ${ }^{\mathrm{b}}$, A. Javor ${ }^{\mathrm{a}}$, A. Hrković-Porobija ${ }^{\mathrm{b}}$, T. Goletic ${ }^{\mathrm{c}}$, \\ G. Gulyas ${ }^{a}$ and L. Czegledi ${ }^{\text {** }}$
anstitute of Animal Science, Biotechnology and Nature Conservation, University of Debrecen, H-4032, Debrecen, Böszörményi út 138. Hungary University of Sarajevo, 90 Zmaja od Bosne, 71000 Sarajevo. Bosnia and Herzegovina \\ ${ }^{b}$ Department of Physiology, ${ }^{\mathrm{c}}$ Department of Avian Diseases and Management, Veterinary Faculty,
}

(Received: 18 December 2014; accepted: 26 January 2015)

\begin{abstract}
Species identification in food has become a prominent issue in recent years as the importance of consumer protection has increased. DNA-based species identification methods were developed by researchers in the last two decades, as these are reliable, accurate, and low-cost techniques for species identification in raw and processed food products as well. In our study, universal primers were designed to conserved regions of mitochondrial $12 \mathrm{~S}$ rRNA. Amplicons were heat-denatured and a PCR single strand conformation polymorphism (SSCP) method was developed to identify cattle, buffalo, sheep, and goat DNA. Sensitivity of this technique was tested on DNA mixtures of cattle-sheep, cattle-goat, and cattle-buffalo and the threshold limit of cattle DNA was 5\%,5\%, and 3\%, respectively. One hundred and five cheeses were purchased and collected from Bosnian and Hungarian farmers, retails, and supermarkets to reveal fraud, 32 percent of them ( 34 cheeses) were found to be mislabelled by species.
\end{abstract}

Keywords: milk species, fraud, PCR-SSCP, 12S rRNA

Livestock species identification in food has received increasing attention in the last two decades. Deceptive and fraudulent behaviour of unfair producers impair the consumers and fair manufacturers. Species identification of dairy products, such as commercial cheeses, has outstanding importance, because some proteins may cause allergic reactions in the human body. One of the most common foods responsible for allergic reactions is cow milk. It is a major source of anaphylactic reactions during infancy (MALMHEDEN YMAN, 2004). However, allergic reaction is not the only problem, but the misdescription of dairy products and replacement of expensive and high quality milk with a cheap and low quality milk impair the consumers and religion questions are raised on the issue of foodstuff adulteration as well (Abdel-Rahman \& Ahmed, 2007; Locci et al., 2008).

In recent decades, many analytical and molecular biological techniques were developed by researchers worldwide, simultaneously with the spread of foodstuff adulterations (MAYER, 2005). Beside protein methods and fatty acid composition analysis, a number of DNA based techniques were applied for species identification.

Most DNA methods are based on PCR (polymerase chain reaction) with the theoretical background that milk derived from the healthy udder of ruminants contains a large number of somatic cells, e.g. leukocytes, predominantly. These cell populations are used as a source of genomic and mitochondrial DNA, which are suitable for PCR reactions (AMILLs et al., 1997).

\footnotetext{
* To whom correspondence should be addressed.

Phone: +36-52-508 444/88199; fax: +36-52-486 285; e-mail: czegledi@agr.unideb.hu
} 
Papers studied variable and conserved regions of mitochondrial genes, such as $12 \mathrm{~S}$ rRNA (López-Calleja et al., 2005, 2007), 16S rRNA (Ghovvati et al., 2009; NAtoneKWiŚNIEWSKA et al., 2013), cytochrome b (Doosti et al., 2014), cytochrome oxydase subunit I (HAider et al., 2012), D-loop (MANE et al., 2009) sequences with duplex-, multiplex-PCR, PCR-RFLP, and DNA sequencing.

The aim of this study was to design universal primers for the same regions of $12 \mathrm{~S}$ rRNA mitochondrial gene of cattle, buffalo, sheep, and goat. Target DNA region of control (species known) milk samples and commercial cheese samples was amplified in single PCR reaction and species specific patterns were determined by SSCP method on polyacrylamide gel. The PCR assay was validated by amplifications of control samples mixed to a certain degree with known DNA concentrations.

\section{Materials and methods}

\subsection{Samples}

Milk of cattle, buffalo, sheep, and goat were obtained from commercial dairy farms in Hungary. Fresh samples were collected in a $50 \mathrm{ml}$ centrifuge tube and transported to the laboratory, stored at $-20^{\circ} \mathrm{C}$ until further analysis. Cheeses were purchased from hypermarkets in Debrecen, Hungary and Travnicki sheep cheeses were collected in Bosnia and Herzegovina. Cheese samples were stored at $-20^{\circ} \mathrm{C}$.

\subsection{Extraction and quantification of DNA}

Genomic DNA was extracted from $1000 \mu \mathrm{l}$ milk of cattle, buffalo, sheep, and goat according to ZsOLNAI and ORBÁN (1999) with slight modifications. In brief, milk fat was discarded after centrifugation at 13000 r.p.m., 5 min. The DNA of cheese samples was isolated from $70 \mathrm{mg}$ of cheese according to DE and co-workers (2011). DNA concentration and quality were measured with NanoDrop 1000 (Thermo Fisher Scientific, USA) spectrophotometer.

\subsection{Primer design}

Nucleotide sequences of 12S rRNA of cattle (GQ926965.1), goat (GQ926969.1), sheep (JQ622016.1), and buffalo (GU119953.1) were used from NCBI GenBank database. Nucleotide sequences were aligned by CLUSTALW2 algorithm of European Bioinformatics Institute (Fig. 1). The universal forward and reverse primers produce a $279 \mathrm{bp}, 281 \mathrm{bp}, 282$ bp, and $283 \mathrm{bp}$ amplicons for cattle, goat, sheep, and buffalo, respectively. Primers were tested by Oligoanalyzer for self-dimer and hetero-dimer structures.

\subsection{PCR assay with universal primers}

The PCR amplification of DNA from milk and cheese was carried out in $20 \mu 1$ volume containing $4 \mathrm{mM} \mathrm{MgCl}_{2}$ (Fermentas), $200 \mu \mathrm{M}$ dNTP mix (Fermentas), 10x Dream Taq buffer (Fermentas), 2 pmoles reverse primer R (5' TTTACTGCTAAATCCTCCTT 3') (Sigma), 2 pmoles forward primer F (5' ACTCTAAGGACTTGGCGGTG 3') (Sigma), 1U Dream Taq polymerase (Fermentas) and 100 ng DNA template. The PCR amplification was running in an ABI Gene Amp 9700 PCR System. The PCR was made of discrete steps, first step is denaturation at $95{ }^{\circ} \mathrm{C}$ for $1.5 \mathrm{~min}$, followed by 35 cycles consisting of denaturation at $95{ }^{\circ} \mathrm{C}$ for $0.5 \mathrm{~min}$, primer annealing at $60{ }^{\circ} \mathrm{C}$ for $0.5 \mathrm{~min}$, and extension at $72{ }^{\circ} \mathrm{C}$ for $0.5 \mathrm{~min}$. The final extension step was 5 min. 


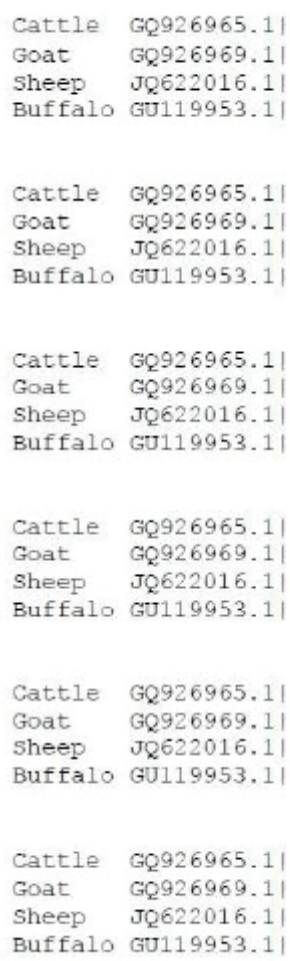

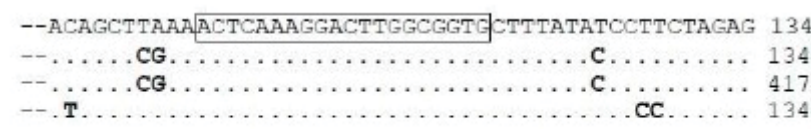

GAGCCTGTTCTATAATCGATAAACCCCGATAAACCTCACCAATTCTTGCT 184
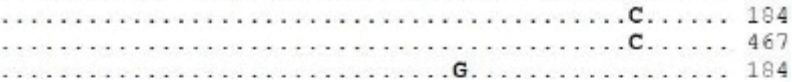

AA-TACAGTCTATATACCGCCATCTTCAGCAAACCCTAAA-AA-GGAAAA 231

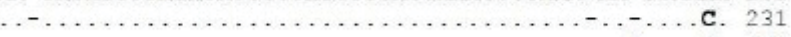

ATGAAATGGGAAGAAATGGGCTACATTCTCTACACCAAGAG-AATCAA-G 329 .G. . . . . . . . . . . . . 328

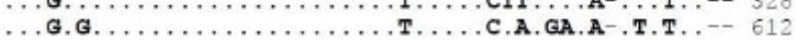

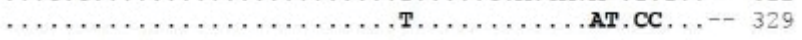

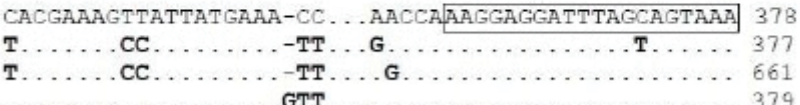

Fig. 1. Multiple alignment of $12 \mathrm{~S}$ rRNA sequences

Amplified PCR products were resolved in 2\% (w/v) agarose gel (Lonza) for $1 \mathrm{~h}$ at $100 \mathrm{~V}$ in TAE (Tris-acetate-EDTA, pH: 8) (Lonza) buffer and stained by GelRed (Biotium, USA).

\subsection{PCR-single strand conformation polymorphism (PCR-SSCP)}

Previously amplified PCR products were heat-denatured at $95{ }^{\circ} \mathrm{C}$ for $5 \mathrm{~min}$ in the presence of $90 \%(\mathrm{v} / \mathrm{v})$ formamide-dye $(8 \%(\mathrm{v} / \mathrm{v})$ bromophenol blue, xylene cyanol stain (Sigma); $92 \%$ (v/v) formamide) and chilled on ice. Single stranded fragments were loaded into a $10 \%$ acrylamide:bis-acrylamide (39:1) non-denaturing polyacrylamide gel $(20 \mathrm{~cm} \times 16 \mathrm{~cm} \times 0.75$ $\mathrm{mm}$ ). Polyacrylamide gel electrophoresis was performed at $10^{\circ} \mathrm{C}$ for $10 \mathrm{~h}$ with $20 \mathrm{~V} \mathrm{~cm}^{-1}$.

SSCP bands on polyacrylamide gel were visualized by silver staining method (MERILL et al., 1984) and documented by Uvipro Platinum (Uvitec) gel documentation system.

\section{Results and discussion}

\subsection{PCR-single strand conformation polymorphism}

Before SSCP analysis, PCR amplicons were verified by agarose gel electrophoresis. A sharp DNA band was detected at each DNA sample extracted from milk and cheese of cattle, goat, sheep, and buffalo as well (Fig. 2). During the PCR-SSCP method, PCR products were 
separated in polyacrylamide gel. Due to denaturation, each DNA-strand formed unique, species-specific conformations, thus each milk species can be differentiated from each other. Polyacrylamide gel electrophoresis of PCR product gave no false positive patterns (Fig. 3).

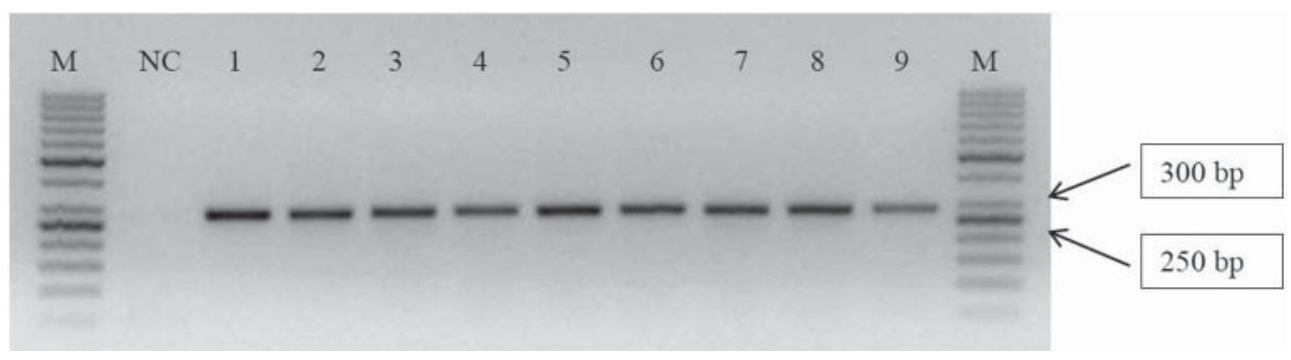

Fig. 2. Electrophoretic analysis of the $12 \mathrm{~S}$ rRNA PCR products on agarose gel. M: 50 bp DNA ladder; NC: negative control; lane 1: cow milk; lane 2: goat milk; lane 3: sheep milk; lane 4: buffalo milk; lane 5: sheep cheese; lane 6: sheep and cow cheese; lane 7: goat cheese; lane 8: goat and cow cheese; lane 9: cow cheese

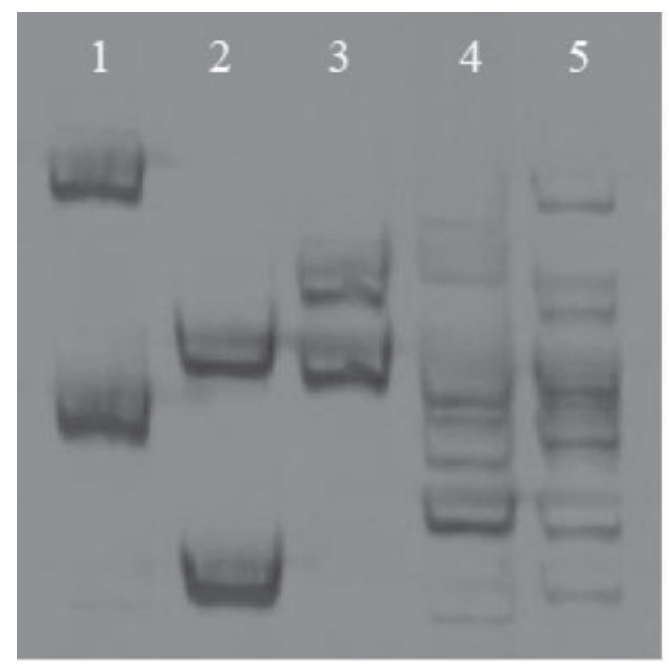

Fig. 3. PCR-SSCP pattern of 12S rRNA of milk species. 1: cattle; 2: buffalo; 3: sheep; 4: goat; 5: DNA mix of all species

These results prove that the designed universal primers could unambiguously discriminate between cattle, goat, sheep, and buffalo species. To evaluate the sensibility of the method, an experimental design was tested with different DNA dilution series. Cattle DNA was mixed with sheep, goat, and buffalo DNA, each DNA mixture contained cattle DNA in $0.1,0.5,1,3,5,10,20,30,40$, and $50 \%$. Control samples were cattle, sheep, goat, and buffalo DNA in $100 \%$. The detection threshold of the PCR-SSCP method in case of buffalo-cattle DNA mixture was 3\% presence of cattle DNA and 5\% of cattle DNA for goatcattle and sheep-cattle DNA mixtures (Figs 4; 5). The DNA bands were detected by Uvipro Platinum (Uvitec) software. The documented gel was analysed by Gel Analysis function of Uvipro Platinum (Uvitec) gel documentation software. The volume of each DNA band was calculated based on pixel intensity data with Uvipro Platinum software. 
A

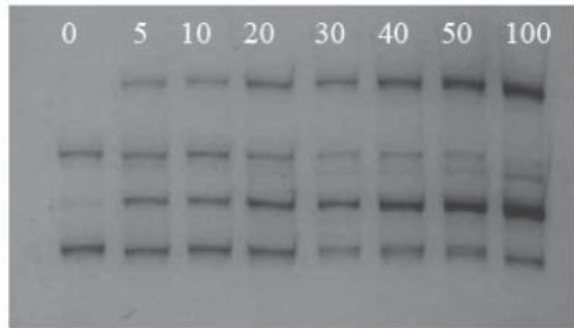

C

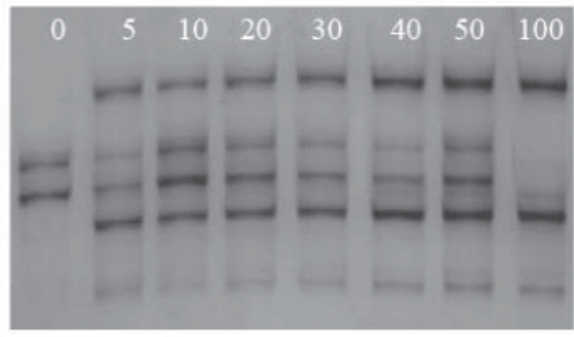

E

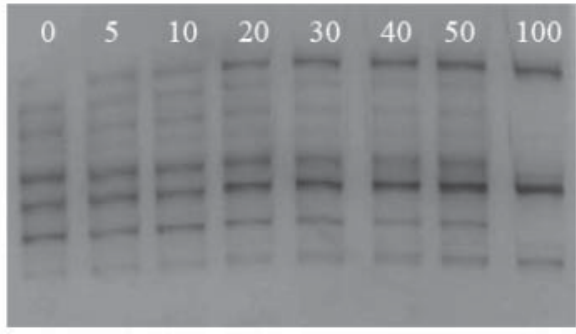

B

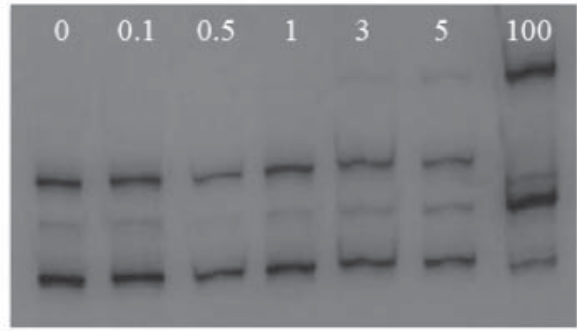

D

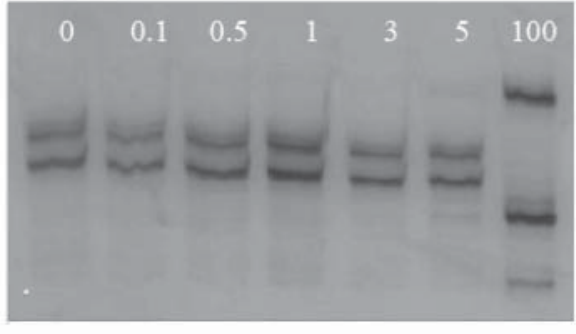

F

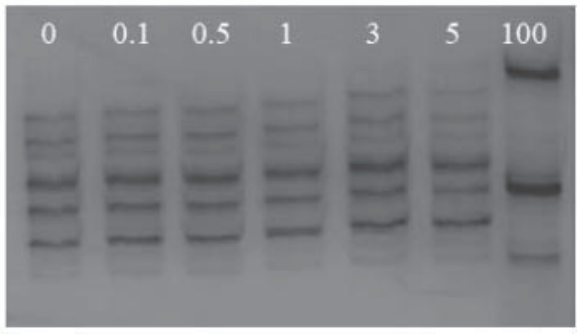

Fig. 4. Electrophoretic analysis of PCR SSCP from mixtures of cow, buffalo, sheep, and goat milk DNA. A: 0, 5, $10,20,30,40,50$, and 100\% cow DNA in cow/buffalo DNA mixture; B: 0, 0.1, 0.5, 1, 3, 5, and 100\% cow DNA in cow/buffalo DNA mixture; C: 0, 5, 10, 20, 30, 40, 50, and 100\% cow DNA in cow/sheep DNA mixture; D: 0, $0.1,0.5,1,3,5$, and $100 \%$ cow DNA in cow/sheep DNA mixture; E: 0, 5, 10, 20, 30, 40, 50, and 100\% cow DNA in cow/goat DNA mixture; F: $0,0.1,0.5,1,3,5$, and $100 \%$ cow DNA in cow/goat DNA mixture

\section{Cattle DNA band}

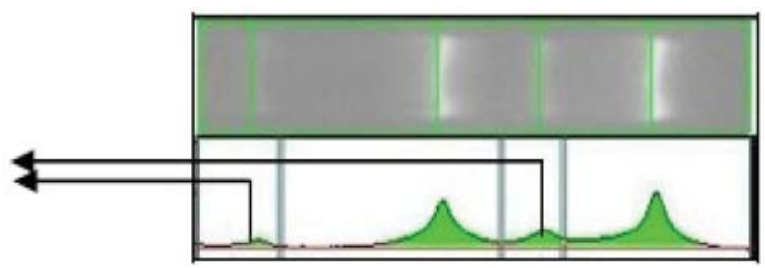

Fig. 5. Volumes of PCR product bands of cattle (3 v/v\%) and buffalo (97 v/v\%) DNA mixture 
Applicability of studied PCR-SSCP method was tested on 105 commercial cheese samples from hypermarkets and retails. Sixty-four cheeses were labelled as sheep milk cheeses, 16 cheeses were made of cow milk, 11 cheeses were made of goat milk, 13 cheeses were labelled as sheep and cow cheeses, and 1 cheese was labelled as made of goat and cow milk. The presence of undeclared species was detected in 34 cheeses $(32.4 \%)$ from the analysed samples. Regarding sheep cheeses, $59.4 \%$ of them (38 of 64 cheeses) contained only sheep DNA, $23.4 \%$ of cheeses were made of sheep and cattle milk, and in $17.2 \%$ of the cheeses only cattle DNA was detected. In each cow cheese only the presence of cattle DNA was proved. Eleven goat cheeses were involved in the study, $54.5 \%$ of them contained goat and cattle DNA, $45.5 \%$ contained only goat DNA. Thirteen cheeses were labelled as made of sheep and cow milk, 84.6\% (11 products) of 13 cheeses contained sheep and cattle DNA, in one cheese only sheep DNA, and in another only cattle DNA were detected. One cheese was labelled as goat and cow cheese and this cheese was confirmed as no fraud, it contained the indicated species.

Cow milk is cheaper than other milk, such as sheep, goat, or buffalo. Consequently, one can expect that if there is a fraudulent, a low cost milk will replace an expensive one in a certain amount. Twenty-nine of 30 cheeses labelled as cow milk proved to contain cow DNA, the only exception was a sheep and cow cheese, in which no cattle DNA was found. This latter finding may be due to the detection limit of this SSCP method. Results of commercial cheese products are listed in Table 1.

Table 1. Identification of species in commercial cheese samples with PCR-SSCP

\begin{tabular}{lcc}
\hline Label (species) & Number of cheeses & Detected species by PCR-SSCP \\
\hline Sheep & 64 & 38 sheep \\
& & 15 sheep + cow \\
& 16 & 11 cow \\
Cow & 11 & 16 cow \\
Goat & 13 & 6 goat + cow \\
Sheep and cow & & 5 goat \\
& 1 & 11 sheep + cow \\
Goat and cow & 1 sheep \\
\end{tabular}

Consumers' demands have increased regarding quality of foodstuffs in recent years. In parallel with these increasing demands, the European consumer protection authorities have created a number of regulations in order to suppress food adulteration. The European Union has legislated Commission Regulations that contain rules concerning labelling of foodstuffs and public information for consumers (COMmission Regulation, No. 1898/2006).

Increasing demands of consumers and governmental regulations infer the development of different analytical techniques for detection of adulteration in food industry. A number of DNA-based methods outstand among these procedures, because these techniques have several advantages in contrast to fatty acid analysis and protein-based methods, such as high sensitivity, reproducibility, applicability, and these are cost-effective techniques in species 
identification practice (DE et al., 2011). The simplest form of PCR-based methods is singlePCR, using one primer pair to detect the presence of specified species (SANTOS et al., 2012).

This paper reports a PCR-SSCP method for the detection of cow, sheep, and goat milk in commercial cheeses. The target of this study was a highly conserved region of mitochondrial 12S rRNA gene. Designed primers allowed the amplification of DNA sequences of milk species in parallel. In cattle-buffalo DNA mix, the detection limit was $3 \mathrm{ng}$ for cattle DNA and it was $5 \mathrm{ng}$ in cattle-sheep and cattle-goat DNA mixture. In other studies researchers published different detection limits. ZHA and co-workers (2010) have described $1 \mathrm{ng}$ of porcine, $5 \mathrm{ng}$ of poultry, and $0.5 \mathrm{ng}$ of bovine meat detection limit in a multiplex-PCR assay.

In a former PCR-SSCP study, seven fish species from Sparidae family were included and five of them were successfully differentiated from each other (SCHIEVENHÖVEL \& REHBEIN, 2013). SRIPHAIROJ and co-workers (2010) have been conducted a successful species identification work on 5 Pangasiid species by PCR-SSCP. The mobility of single-stranded DNA in polyacrylamide gel depends on its specific conformation(s) that is determined by nucleotide sequence. Beside this primary factor, duration of electrophoresis (REHBEIN, 2005), acrylamide/bis-acrylamide ratio, gel concentration, buffer concentration, and temperature also influence the mobility of DNA fragments (HAYASHI, 1991).

\section{Conclusions}

In this study, the applicability and detection limit of PCR-SSCP method for milk species differentiation was studied. The application of this method was tested on 105 commercial cheeses and sensitivity threshold was tested on sheep-cattle, goat-cattle, and buffalo-cattle $0.1,0.5,1,3,5,10,20,30,40,50 \%$ DNA mixtures. In each species mixture cattle DNA was detected at $5 \%$ ratio, however, the sensitivity of the method was better for buffalo-cattle DNA mix, as cattle DNA was detected at the concentration of $3 \%$. Undeclared species were found in 34 of 105 commercial cheeses from Bosnian markets and Hungarian hypermarkets. Based on our results we found that PCR-SSCP protocol, described in this paper, is a reliable, lowcost, and appropriate method to detect species in milk and milk products, such as cheese. In practice, this assay can be an appropriate, DNA based tool to detect fraudulent adulteration of milk species. For future work, we plan to develop and apply a capillary electrophoresis SSCP method, which might be a more sensitive technique compared to polyacrylamide electrophoresis, to increase sensitivity for fraud detection (GARCíA-CANAS et al., 2004; ICHIM, 2011).

This work was supported by Federal Ministry of Education and Science, Federation of Bosnia and Herzegovina, $\mathrm{B} \& \mathrm{H}$.

\section{References}

Abdel-Rahman, S.M. \& Ahmed, M.M.M. (2007): Rapid and sensitive identification of buffalo's, cattle's, and sheep's milk using species-specific PCR and PCR-RFLP techniques. Food Control, 18, 1246-1249.

Amills, M., Francino, O., Jansa, M. \& SÁnchez, A. (1997): Isolation of genomic DNA from milk samples by using Chelex resin. J. Dairy Res., 64, 231-238.

Commission Regulation (2006): The protection of geographical indications and designations of origin for agricultural products and foodstuffs. EC no 1898/2006 of 23 December 2006. OJ, L369, 1-19. 
De, S., Brahma, B., Polley, S., Mukherjee, A., Banerjee, D., Gohaina M., Singh, K.P., Singh, R., Datta, T.K. \& Goswami, S.L. (2011): Simplex and duplex PCR assays for species specific identification of cattle and buffalo milk and cheese. Food Control, 22, 690-696.

Doosti, A., Dehkordi, P.G. \& Rahimi, E. (2014): Molecular assay to fraud identification of meat products. J. Food Sci. Tech., 51, 148-152.

García-Canas, V., GonzÁlez, R. \& Cifuentes, A. (2004): The combined use of molecular techniques and capillary electrophoresis in food analysis. Trends Anal. Chem., 23, 637-643.

Ghovvati, S., Nassiri, M.R., Mirhoseini, S.Z., Heravi Moussavi, A. \& Javadmanesh, A. (2009): Fraud identification in industrial meat products by multiplex PCR assay. Food Control, 20, 696-699.

Haider, N., NABulsi, I. \& Al-SAfadi, B. (2012): Identification of meat species by PCR-RFLP of the mitochondrial COI gene. Meat Sci., 90, 490-493.

HAYASHI, K. (1991): PCR-SSCP: a simple and sensitive method for detection of mutations in the genomic DNA. PCR Meth. Appl., 1, 34-38.

IcHIM, M.C. (2011): High-throughput screening for single nucleotide polymorphisms (SNPs) in specific DNA fragments by automated SSCP-based capillary electrophoresis. Curr. Opin. Biotech., 22, 103-104.

Locci, F., Ghiglietti, R., Francolino, S., Iezzi, R., Oliviero, V. \& Garofalo, A. (2008): Detection of cow milk in cooked buffalo mozzarella used as pizza topping. Food Chem., 107, 1337-1341.

López-Calleja, I., González Alonso, I., Fajardo, V., Rodríguez, M.A., Hernández, P.E., García, T. \& Martín, R. (2005): PCR detection of cows' milk in water buffalo milk and mozzarella cheese. Int. Dairy J., 15, 1122 1129.

López-Calleja, I., González, I., Fajardo, V., Hernández, P.E., García, T. \& Martín, R. (2007): Application of an indirect ELISA and a PCR technique for detection of cows' milk in sheep's and goats' milk cheeses. Int. Dairy J., 17, 87-93.

Malmheden Yman, I. (2004): Detection of inadequate labelling and contamination as causes of allergic reactions to food. Acta Alimentaria, 33, 347-357.

Mane, B.G., Mendiratta, S.K. \& Tiwari, A.K. (2009): Polymerase chain reaction assay for identification of chicken in meat and meat products. Food Chem., 116, 806-810.

MAYER, H.K. (2005): Milk species identification in cheese varieties using electrophoretic, chromatographic, and PCR techniques. Int. Dairy J., 15, 595-604.

Merill, C.R., Goldman, D. \& Van Keuren, M.L. (1984): Gel protein stains: Silver stains. Methods Enzimol., 104, $441-447$.

Natonek-Wiśniewska, M., Krzyścin, P. \& Piestrzyńska-Kajtoch, A. (2013): The species identification of bovine, porcine, ovine and chicken components in animal meals, feeds and their ingredients, based on COX I analysis and ribosomal DNA sequences. Food Control, 34, 69-78.

Rehbein, H. (2005): Identification of the fish species of raw or cold-smoked salmon and salmon caviar by singlestrand conformation polymorphism (SSCP) analysis. Eur. Food Res. Technol., 220, 625-632.

Santos, C.G., Melo, V.S., Amaral, J.S., Estevinho, L., Oliveira, M.B.P.P. \& Mafra, I. (2012): Identification of hare meat by a species-specific marker of mitochondrial origin. Meat Sci., 90, 836-841.

Schievenhövel, K. \& Rehbein, H. (2013): Differentiation of Sparidae species by DNA sequence analysis, PCRSSCP and IEF of sarcoplasmic proteins. Food Chem., 138, 154-160.

Sriphairoj, K., Klinbu-NGa, S., Kamonrat, W. \& NA-NaKorn, U. (2010): Species identification of four economically important Pangasiid catfishes and closely related species using SSCP markers. Aquaculture, 308, 47-50.

ZHA, D., XING, X. \& YAnG, F. (2010): A multiplex PCR assay for fraud identification of deer products. Food Control, $21,1402-1407$.

ZsolnAi, A. \& ORBÁN, L. (1999): Accelerated separation of random complex DNA patterns in gels: comparing the performance of discontinuous and continuous buffers. Electrophoresis, 7, 1462-1468. 